\title{
PERCEIVED INFLUENCE OF RELATIONSHIP COMMUNICATION ON INSURANCE SERVICE QUALITY AND CUSTOMER SATISFACTION
}

\author{
Andem I. Effiong \\ Arthur Jarvis University, Calabar, Nigeria \\ Wilmington University, DE, United States \\ E-mail: andyeffiong@gmail.com
}

Submission: $20 / 04 / 2018$

Accept: 29/05/2018

\section{ABSTRACT}

Extant literature in marketing and communications has long recognized the importance of effective communication as the essential link for sustainable relationship between organizations and their customers. In spite of its importance, many studies have revealed that practices of communication in relationship marketing in some service firms are fraught with problems, which influence the perceptions of customers about the commitment of those organizations to service quality and customer value. This exploratory study was undertaken to analyze how insurance customers perceive their relationships with insurers through received messages. The study also sought to identify the inherent differences in the perception of relational messages received from insurers by the customers based on gender. A simple random sample of 145 insurance customers were drawn for the study from three insurance agencies. Useful responses were received from 120 automobile insurance policyholders, which represented $82.76 \%$ of the sample. Four hypotheses were tested with Pearson Correlation, one-way analysis of variance (ANOVA), and multiple regression analysis. The results of the study suggested significant relationship between relational messages, service quality, and customer satisfaction. In terms of differences in the perceptions of male and female respondents, the study indicated significant differences in the perception of personal values and perceived quality through messages received from insurers depending on the time and situational contexts. 
Similarly, significant differences were recorded in the perception of message credibility by the female participants as compared with those of the males. The study also revealed the need for insurance companies to fully imbibe relationship communication with their customers, through assessment of the internal and external situations, which surround the information needs of individual customers.

Keywords: Relationship communication, relationship marketing, relational message, meanings of message, service quality, customer satisfaction, perception, situation

\section{INTRODUCTION}

Within the past two decades, marketing communication has witnessed dramatic changes, which have not only impacted on the systems and strategies of organizations; but also seem to have influenced the perceptions and buying decision processes of customers. Most of those changes have been associated with the emergence of the internet and information technology as the catalysts that have transformed business communication and social interactions in un-imaginable ways (SORCE, 2002). The immediate impact of the transformation seems to be the relegation of interpersonal relationships, through face-to-face communications to the background in some major business interactions. It has also led to over-reliance on the computers and the virtual media as the main channels of communication between most organizations and their customers.

With such changes, some organizations also seem to have neglected the importance of problem solving and information gathering through personal contacts with customers. Above all, business communications in some organizations have become one sided monologue, which are not oriented to the needs and situations of customers. In that regard, some customers are usually inundated with advertisement and other forms of communication in printed and digital forms, which are not relevant to the customers' needs and desires. Undoubtedly, the outcome may not only involve wasted efforts, time, costs, and other resources to organizations, but can also be a major source of dissonance and apprehension to the customers.

Although the importance of relationship communication had been recognized as a key strategy in relationship marketing for over three decades, specific theories that pin the concept to the insurance industry are scarce. 
INDEPENDENT JOURNAL OF MANAGEMENT \& PRODUCTION (IJM\&P)

http://www.ijmp.jor.br

v. 10, n. 1, January - February 2019

ISSN: 2236-269X

DOI: 10.14807/ijmp.v10i1.829

As Kodish and Pettegrew (2008) reveal, practices of relationship communication as an integral part of relationship marketing in most service organizations are fraught with problems that limit the impact on the perceptions of most customers about the service quality and commitment of such organizations to customer value. The situation in the insurance industry may not be different. Gidhagen (1998), Yang, Chen and Wang (2010) and Finne and Gronroos (2009) have also argued that business communications in many organizations, including those in the insurance industry seem to be deplorable, in that relationship communication is more of espoused theory than adopted practice. Many managers are still entrenched in the old traditional realm of communications which emphasized transactional instead of relationship orientation.

Relationship communication has been defined by Finne and Gronroos (2009) as "any type of marketing communication that influences the receiver's long term commitment to the sender by facilitating meaning creation through integration with the receiver's time and situational context. The time context refers to the receiver's perception of the history and envisioned future of his/her relationship with the sender. The situational context refers to other elements, which are internal and external to the receiver (p. 180)." One of the tenets of relationship communication is that organizations do not operate in a vacuum.

Organizations operate in the internal and external dimensions of the environment which are inhabited by people. Therefore, the silo or the transactional theory of communication which was driven by the internal organizational values may be less appealing to the well informed customers of the new millennium. With a high level of education and the quality of information presently at the disposal of customers through the internet, an orientation which emphasizes the goals of the organization and the intrinsic and extrinsic values of customers in marketing communication appears to be indispensable.

The purpose of the study was to identify how insurance customers perceive the communication messages they receive from insurers. Secondly, the study aimed to analyze the inherent differences in the perceptions of male and female insurance customers on service quality and customer satisfaction based on messages they receive from their insurers. The questions addressed in the study were as follows: 
(a) Do insurance customers relate the messages they receive from insurers with service quality?

(b) What is the relationship between messages received from insurers and customers' satisfaction?

(c) Are there differences in the levels of association of messages with service quality by male and female insurance customers?

(d) What are the differences in the perceptions of relational messages and levels of customer satisfaction based on the gender of policyholders?

The study was exploratory in nature. It covered the perception of insurance service quality and policyholders' satisfaction from the perspective of automobile insurance buyers who were domiciled in the States of Pennsylvania, Delaware, and Connecticut, USA in 2016. This research report is divided into six sections. Section one covers the introduction. Section two presents the literature review. The research method is covered in section three. Data analysis and results are captured in section four. Section five presents the discussion; and section six gives the conclusion and implications.

\section{LITERATURE REVIEW}

The volume of literature in relationship marketing and relationship communications is enormous. Most of the existing literature regards relationship communication as an integral part and a key strategy of relationship marketing. Conversely, some researchers in communication processes and theories tend to relate relationship communication with human resource management; while most organizational behaviorists consider the concept as a key role in leadership and motivation.

The apparent disagreement tends to portray the complexity in maintaining relationships through communication, which are boundary spanning. Berlo (1960) saw the complexity to be inherent in communication as a process that is highly interdependent and inter-relational. Communication as a tool of relationship can be conceptualized as a multi-dimensional process involving:

a) people (sender and receiver),

b) messages and meanings, 
c) the link or mode of transmission,

d) relational exchanges,

e) time, and

f) situations, amongst other elements.

Communication can make or mar relationships depending on the nature of inputs, the mode of transmission, the interpretation processes, the relative output, and the internal and external situations.

In the past, business communication theories hinged purely on transfer of meanings which Axley (1984) described as ineffective, because of the apparent disregard by the sender's prevailing situations and the future expectations of the receiver. In the same vein, many researchers have also exposed the inherent weaknesses of the transfer or conveyor theory of business communication which ignored the potential misinterpretations or misunderstanding of messages by the receiver in the design and implementation processes (KRAUSS; MORSELLA, 2000; HUTTON; MULHERN, 2003; THRASSOU; VRONTIS, 2009).

Undoubtedly, the paradigm shift in marketing communication from the transactional to relationship orientation was the outcome of the realization of the value of the customer as a partner in the communication process. That shift in orientation was a major transformation from the hitherto manipulative to the new "reflex-style consumer and symbiotic relationships, which were induced by the incessant changes in the macro and micro environments of business" (THRASSOU; VRONTIS, 2009 p. 514).

\subsection{Communication in the Domain of Relationship Marketing}

Communication in marketing has changed at an alarming pace (KOTLER; KELLER, 2012). The pace of change has been associated not only with the dramatic switch in technology and other factors in the environment of business, but also because of increased awareness and the ease of social interaction experienced by the customer of the new millennium, through the electronic media and the internet.

This wave of social interaction appears to have molded a new set of better informed and relatively calculative customers whose decisions to be involved in business relationships are subject to internal and external assessment of long term 
values. Contemporary marketing communication from the perspective of the informed customers has therefore evolved into what Thrassou and Vrontis (2009 p. 514) called "symbiotic relationship".

The new perspective tends to support the earlier propositions by Berry (1983) that organizations need to think in terms of having and retaining customers instead of merely acquiring new customers. That shift in mental framing and orientation towards long term relationships with customers prompted the introduction of the concept which Berry labeled as relationship marketing.

Relationship marketing aims at "attracting, maintaining, enhancing and commercializing customer relationships" (BERRY, 1995 p. 236) in a manner that will facilitate the attainment of goals of the organization as well as the short and long term values of the customer.

Marsey et al. (1995), conceptualized relationship marketing to comprise:

a) orientation to customer retention,

b) continuous customer contact,

c) focus on customer value,

d) long time dimension,

e) high customer service emphasis,

f) high commitment to meet customer expectations, and

g) quality concern by all staff.

Relationship communication as a tool of relationship marketing involves continuous contact with the customer to develop symbiotic relationships from the external marketing environment to the internal context of the organization and from the tangible and the intangible dimensions of products and services which meet the intrinsic and extrinsic values that emanate from the needs and desires of customers.

Verhoef (2003) views marketing relationship through communication with customers as the differential advantage which accrues to firms that are committed to customer value for the enhancement of effective customer response. Relationship communication between the organization and the customer has also been described 
DOI: 10.14807/ijmp.v10i1.829

as a market-based investment for maintenance of stability and viability in a competitive business environment (SORCE, 2002).

\subsection{Relationship Communication in Insurance Marketing}

Most of the previous studies in insurance marketing and communications focused extensively on the transactional and conveyor-belt theories of communication. The aim was to create a hierarchical impact on the customer, who was supposed to be convinced through some unique sales propositions that moved him/her from a state of unawareness to awareness, interest, desire, conviction, and action.

The conveyor-belt theory of communication is mechanistic oriented while relationship communication theory is organismic in nature (PERCY; ELLIOTT, 2005). The conveyor-belt theory regards communication as a message which originates from an encoder through a channel to a passive receiver who decodes the message and may or may not respond to the sender/encoder (DUNCAN; MORIARTTY, 1997; DUNCAN, 2005; PICKTON; BRODERICK, 2005). That general belief on transactional theory of communication led to the proposition of the first Null Hypothesis for the study as follows:

- $\mathrm{H}_{0}$ : There are no significant linkages between relationship communication and insurance policyholder's perception of service quality.

On the other hand, relationship communication is conceptualized as a multidimensional and interactional process which originates from the domain of the customer whose needs and values are understood. The understanding emanates from the data-based attributes, which are maintained by an organization that readily translates the attributes into products or services which are desired by the customer to satisfy his/her impinging needs (KOTLER; KELLER, 2012).

Bolton and Bhattacharya (2000) posit that relationship marketing of services (including insurance) requires customer intimacy, two way interactions through frequent flow of communication, amongst other facilitating conditions. Most insurance contracts involve protection against pure risks of loss which are fortuitous and uncertain in nature, and the relational exchange may require multiple episodes of one-to-one contacts in order to generate the intimacy that can build confidence and trusts, which the electronic tools alone may not be able fulfill. 


\subsection{Relationship Communication and Insurance Service Quality}

Most studies on relationship communication have proposed the recognition of customers as "customers" (SHARMA; PATTERSON, 1999, p. 6). In that respect, organizations need to understand that customers do not buy products or services but they buy the experience associated with the products/services.

Relationship communication can become a major benchmark for comparison and evaluation of service quality delivery. In the same vein, communication effectiveness has been found to be the most powerful determinant of relationship commitment in the service industry (SHARMA; PATTERSON, 2000; ABUROUB; HERSH; ALADWAN, 2011).

Parasuraman, Zeithmal, and Berry (1988) have provided one of the most useful insights into the factors which can influence customers' perception of service quality to include:
a) reliability,
b) responsiveness,
c) assurance,
d) empathy, and
e) physical evidence.

These factors have also been found to have significant relationships with customers' interpretation of meanings in communications and interactions between service providers and customers (SHARMA; PATTERSON, 1999; ALLERD, 2001).

Research on antecedents of service quality involving communications and relationship marketing has provided substantial evidence of significant association between service quality, customer satisfaction, and loyalty of customers in the service industry.

Crosby, Evans, and Cowles (1990) have revealed that customer expectation about future value can best be determined by the relationship quality of the sales team and the service provider communication integrity. Although empirical studies that link insurance services to relationship communication are skimpy and quite difficult to come by, it appears the belief in most service industries is that customers' 
INDEPENDENT JOURNAL OF MANAGEMENT \& PRODUCTION (IJM\&P)

http://www.ijmp.jor.br

v. 10, n. 1, January - February 2019

ISSN: 2236-269X

DOI: 10.14807/ijmp.v10i1.829

perception of service quality may depend more on commitment to benefits delivery that portrays transactional orientation than on symbiotic relationship communication, which could be only promissory in nature. The increased emphasis on the need for quality in the service marketing literature led to the formulation of the alternative hypothesis as follows:

- $\mathrm{H}_{\mathrm{a} 1:}$ There is a significant relationship between relational messages received from insurers and customers' perception of service quality

\subsection{Customer Satisfaction and Relationship Communication}

Customer orientation as an element of the marketing concept has been extensively researched not only because of its relevance as the foundation of the marketing concept, but probably because of its significance as the mediating factor in effective relationship between organizations and their variegated customers. Several studies have shown that customer satisfaction, which evolves from customer orientation could be better understood through self-assessment by the customer (BOLTON, 1998; AGGARWAL-GUPTAR; KUMAR, 2012; MITHAS; KRISHNAN; FORNELL, 2005; BOLTON; LEMON; VERHOEF, 2004).

However, some studies have found that customer satisfaction could have both positive and negative effects on customer behaviour. For instance, a high level of customer satisfaction could result in a strong customer loyalty. Conversely, it may also have a negative effect on customer complaints and ability to query inherent but latent organizational lapses (FORNELL, 1992; BOLTON, 1998; GRONROOS, 2000; KOTLER, 2003). Customer satisfaction as desirable outcome of relationship communication has been emphasized in numerous marketing studies which relate to services at both the internal and external customers levels (KODISH; PETTEGREW, 2008; SHETH; PARVATIYAR, 1995; MARSEY; DAWES, 2007; CHEN; SHI; DONG, 2008).

According to Chen, Shi and Dong (2008, p.9), "meanings of messages are in people". Meanings refer to the interpretations of messages as nurtured and generated by the customers that receive the messages throuh communication channels. Channel of communication is the means of transmission of the message (postal mail, email, person-to-person, television or radio, company website, etc.), Commitment is the degree to which the insured customer feels obligated to remain 
INDEPENDENT JOURNAL OF MANAGEMENT \& PRODUCTION (IJM\&P)

http://www.ijmp.jor.br

v. 10, n. 1, January - February 2019

ISSN: 2236-269X

DOI: 10.14807/ijmp.v10i1.829

with the insurer after receiving official messages. Situation is the prevailing circumstance under which the message is received (MARSEY et al., 1995)

The term Empathy with regards to customer satisfaction means the belief by the customer that the company understands the situation of the customer as portrayed in the message (PARASURAMAN; ZEITHMAN; BERRY, 1988). Customer expectation is the standard of service expected from the company by the customer. Personal value is the recognition accorded the customer as a partner in the business relationship as reflected in the communication process (GRONROOS, 2000) . Reliability is the ability to deliver the quality of services with regard to time, manner, and cost as promised (PARASURAMAN; ZEITHMAN; BERRY, 1988). The term Responsiveness means the readiness of the insurer to respond to the insured as required. Credibility is the trust placed on the marketer by the customer based on experience (KOTLER; KELLER, 2012). Assurance (Physical evidence) is the tangible proof supplied to the customer with regard to specific service performance (PARASURAMAN; ZEITHMAN; BERRY, 1988). The second hypothesis was proposed based on Gronroos' definition of personal value accorded to the customer through relationship communication that would enhance the customer's satisfaction.

- $\mathrm{Ha}_{2}$ There is a significant relationship between relational messages received from insurers and perceived satisfaction by the customers.

\subsection{Interpretation of Messages Based on Gender}

Studies have shown that women, are more sensitive to meanings of messages than men in the exchange of messages with friends and colleagues on matters that relate to business. As Wood (2009) posits, societal expectations often make women responsible for regulating intimacy, or how close they allow others to communicate with them. For that reason, it is argued that women pay more attention than men to the underlying meanings about intimacy or relationship that messages convey.

Men on the other hand, tend to be more sensitive to reading and crosschecking more closely about status, quality, and cost implications in a business relationship. For men, societal expectations are that they must negotiate extensively on matters concerning hierarchy and leadership situations (TANNEN, 1990; WOOD, 2009). 
These perceived differences in perceptions of communication patterns amongst men and women that have been highly emphasized in the communication literature prompted the proposition of the third and fourth alternative hypotheses as follows:

- Наз: There are significant differences between the perceptions of male and female customers on insurance service quality based on relationship messages received from insurers.

- Ha4: There are significant differences between the perceptions of male and female insurance customers with regard to customer satisfaction based on messages from insurers.

\section{RESEARCH METHODOLOGY}

\subsection{Sample Selection}

A simple random sample of 145 customers were selected for the study from lists of registered customers supplied by three insurance agencies. Those selected were mostly automobile insurance customers who had purchased auto insurance policies from different insurance companies.

Most business contacts with the insurers were also routed through the agencies by the policyholders. Some of the questionnaires (80) were sent through emails and 65 were posted through the United States Postal Services (USPS); 120 of the questionnaires were duly completed and returned, which represented $82.76 \%$ of the selected sample. The number of returned and duly completed questionnaires comprised of 75 from males and 45 from female policyholders.

\subsection{Instrument Design}

The research instrument was a 5-point Likert scale questionnaire with variables derived from the extant literature on relationship communication, which include amongst others: (1) meaning of message, (2) perceived commitment, and (3) communication channels (FINNE; GRONROOS, 2009; AGGARWAL-GUPTA; KUMAR, 2012; KODISH; PETTEGREW, 2008; GIDHAGEN, 1998; BERRY, 1995).

Service quality was measured with four key variables: (1) customer expectation, (2) personal value, (3) empathy, and (4) reliability which were also drawn from the literature (PARASURAMAN; ZEITHMAL; BERRY, 1988). Customer 
satisfaction was measured with three variables: (1) credibility, (2) responsiveness, and (3) assurance (physical evidence) which were drawn from the American Customer Satisfaction Index (ASCl), and had been used in several previous studies in marketing (ANDERSON; FORNELL; MAZVANCHERYL, 2004; FORNELL et al, 1996).

Participants were asked to rate structured statements associated with their perceptions of communication from the insurers on a measurement scale of 1 to 5 , in which $1=$ Strongly Disagree, $2=$ Disagree, $3=$ Neutral, $4=$ Agree and $5=$ Strongly Agree

\subsubsection{Reliability Tests}

The reliability of the measures in the research instrument was tested with the Cronbach's Alpha Reliability Statistics. As shown in Tables 1 and 2. The variables and measures had an overall reliability index of .894 while the standardized items reliability index was .901 .

Table 1: Reliability Statistics

\begin{tabular}{|c|c|c|}
\hline Overall Reliability Index & Standardized Items Reliability Index & Number of Items \\
\hline .894 & .901 & 10 \\
\hline
\end{tabular}

Table 2: Item-Total Statistics

\begin{tabular}{|c|l|c|}
\hline Serial & \multicolumn{1}{|c|}{ Variables } & Cronbach's alpha \\
\hline 1 & Meanings of Messages & .891 \\
\hline 2 & Perceived Relational Commitment & .867 \\
\hline 3 & Communication Channels & .903 \\
\hline 4 & Empathy & .879 \\
\hline 5 & Expected Quality & .878 \\
\hline 6 & Perceived Value & .882 \\
\hline 7 & Reliability & .874 \\
\hline 8 & Responsiveness & .884 \\
\hline 9 & Credibility & .891 \\
\hline 10 & Assurance (Physical Evidence) & .880 \\
\hline
\end{tabular}

The instruments were also reviewed and tested with Cohen's kappa to determine the degree of consistency of the measures and the relative responses. The results indicated a high kappa (k) statistic of $0.86(95 \% \mathrm{Cl}, \mathrm{p}<.05)$.

\subsection{Data Analysis and Results}

Descriptive and inferential statistics were used for data analyses. The data for the study were coded and crosschecked for accuracy. Inferential Statistics were used to analyze the coded data after extraction from the returned questionnaires. The data were then entered into data sheet and analyzed with SPSS 22 software 
INDEPENDENT JOURNAL OF MANAGEMENT \& PRODUCTION (IJM\&P)

http://www.ijmp.jor.br

v. 10, n. 1, January - February 2019

ISSN: 2236-269X

DOI: 10.14807/ijmp.v10i1.829

based on the research questions and the relevant hypotheses. The descriptive statistics for the dependent and independent variables are shown in Table 3.

Table 3: Descriptive Statistics

\begin{tabular}{|l|c|c|c|c|c|c|}
\hline \multicolumn{1}{|c|}{ Variables } & $\mathrm{N}$ & Minimum & Maximum & Mean & $\begin{array}{c}\text { Std. } \\
\text { Deviation }\end{array}$ & Variance \\
\hline Meaning of Message & 120 & 3 & 5 & 4.15 & .587 & .345 \\
\hline $\begin{array}{l}\text { Perceived Relational } \\
\text { Communication }\end{array}$ & 120 & 3 & 4 & 3.55 & .510 & .261 \\
\hline Communication Channels & 120 & 3 & 5 & 3.80 & .616 & .379 \\
\hline Empathy & 120 & 2 & 5 & 4.30 & .865 & .747 \\
\hline Expected Service Quality & 120 & 3 & 5 & 4.10 & .718 & .516 \\
\hline Perceived Value & 120 & 2 & 4 & 3.60 & .598 & .358 \\
\hline Reliability & 120 & 3 & 5 & 4.45 & .605 & .366 \\
\hline Responsiveness & 120 & 3 & 5 & 4.25 & .639 & .408 \\
\hline Credibility & 120 & 3 & 5 & 4.30 & .571 & .326 \\
\hline Assurance (Physical Evidence) & 120 & 2 & 5 & 3.80 & 1.105 & 1.221 \\
\hline Gender & 120 & 1 & 2 & 1.45 & .510 & .261 \\
\hline Age & 120 & 25 & 64 & 40.50 & 11.614 & 134.895 \\
\hline Education & 120 & 1 & 3 & 2.30 & .657 & .432 \\
\hline Marital Status & 120 & 1 & 4 & 2.05 & .887 & .787 \\
\hline Occupation & 120 & 2 & 5 & 3.45 & .686 & .471 \\
\hline Rank & 120 & 2 & 4 & 2.50 & .721 & .520 \\
\hline \multicolumn{1}{|c|}{ Valid N (listwise) } & 120 & & & & & \\
\hline
\end{tabular}

The Null Hypothesis $\left(\mathrm{H}_{0}\right)$ was tested with Pearson's Product Moment Correlation $(r)$ at $p \leq .05$ significant levels. The results were as shown in Table 4 below. Each of the four measures of service quality were tested independently with each of the four measures of relationship communication.

The results indicated that meanings of message was perceived as moderately correlated with empathy, weakly correlated with customer expectation, weakly correlated with personal value, and moderately correlated with reliability; coefficient $(r)=.557, .326,, 295$, and .563 respectively.

Similarly, relational commitment were perceived by the respondents to be highly correlated with empathy, customer expectation, and personal value $(r=.765$, .863, \& .732); but moderately correlated with reliability $(r=.539)$. In the same vein, communication channels were shown to be highly correlated with empathy and customer expectation, but weakly correlated with personal value, and reliability ( $r=$ $.653, .814,281$, and.367 respectively).

The relationship between the prevailing situation and the four measures of service quality were found to be moderate in the case of empathy, but high in 
INDEPENDENT JOURNAL OF MANAGEMENT \& PRODUCTION (IJM\&P)

http://www.ijmp.jor.br

v. 10, n. 1, January - February 2019

ISSN: 2236-269X

DOI: 10.14807/ijmp.v10i1.829

customer expectation, personal value, and reliability with $.683, .673$, and .674 respectively. Hence the null hypothesis was rejected in all cases.

Table 4: Pearson Correlation: Relationship Communication and Service Quality

\begin{tabular}{|c|c|c|c|c|}
\hline $\begin{array}{l}\text { Service Quality/Relationship } \\
\text { Communication }\end{array}$ & Empathy & Customer Expectation & Personal Value & Reliability \\
\hline Meanings of Messages & $.557^{*}$ & $.326^{\star}$ & $.295^{\star}$ & $.563^{*}$ \\
\hline Relational Commitment & $.765^{*}$ & $.863^{\star}$ & $.732^{\star}$ & $.539 *$ \\
\hline Communication Channels & $653^{*}$ & $.814^{*}$ & $.281^{*}$ & $.367^{*}$ \\
\hline Prevailing Situation & $.421^{*}$ & $.683^{\star}$ & $.673^{*}$ & $.674^{*}$ \\
\hline
\end{tabular}

The following sections present the analyses and exploration of the research questions and the relevant alternative hypotheses.

(a) Do insurance customers relate the messages they receive from insurers with service quality?

Research question one and the resnt aelevant hypotheses $\left(\mathrm{H}_{1}\right)$ were tested and analyzed with Multiple Regression Analysis at $p<.05$ level. All the four relationship communication measures were treated as the independent variables, while the four service quality measures were taken as dependent variables on iterative basis. As displayed in Table 5, the regression equation could be expressed as: Relational Messages $=2.631-.121$ (message meaning $)+.650($ commitment $)-$ .115 (channels) + error.

The coefficient $t$ score, which shows the significance of each variable was only significant for commitment, but not significant for other variables, $t=3.94, p \leq$ .001 (Table 6). It indicates that the respondents perceived the relationship between commitment in relational messages and service quality to be significant as also shown in Table 7 ( $F=5.391, p \leq .009)$. Hence, $H_{1}$ could not be rejected on the commitment variable, but stands rejected on the other two variables of communication (meanings \& channels).

Table 5: Model Summary

\begin{tabular}{|c|c|c|c|c|}
\hline Model & R & R Square & Adjusted R Square & Std. Error of the Estimate \\
\hline 1 & .709 & .503 & .409 & .473 \\
\hline
\end{tabular}

a. Predictors: (Constant), I receive messages through appropriate channels from my insurers, I feel my insurers are committed when I receive message, Messages from insurers are meaningful to me.

Table 6: ANOVA

\begin{tabular}{|c|c|c|c|c|c|}
\hline Model & $\begin{array}{c}\text { Sum of } \\
\text { Squares }\end{array}$ & df & Mean Square & F & Sig. \\
\hline Regression & 3.619 & 3 & 1.206 & 5.391 & .009 \\
1 Residual & 3.581 & 116 & 224 & & \\
Total & 7.200 & 119 & & & \\
\hline
\end{tabular}


Table 7: Coefficients

\begin{tabular}{|c|ll|l|l|l|l|}
\hline Model & \multicolumn{2}{|c|}{$\begin{array}{c}\text { Unstandardized } \\
\text { Coefficients }\end{array}$} & $\begin{array}{c}\text { Standardized } \\
\text { Coefficients } \\
\text { Beta }\end{array}$ & $\mathrm{t}$ & Sig. & Remarks \\
& $\mathrm{B}$ & Std.Error & \multicolumn{2}{|c|}{} & \\
\hline (Constant) & 2.631 & .837 & & 3.145 & .006 & $\mathrm{~S}$ \\
Meanings of Message & -.121 & .137 & -.183 & & .390 & $\mathrm{NS}$ \\
Relational Commitment & .650 & .165 & .817 & -.883 & .001 & $\mathrm{~S}$ \\
Communication Channels & -.115 & .174 & -.118 & 3.942 & .518 & $\mathrm{NS}$ \\
\hline
\end{tabular}

Legend: NS = Not Significant; S = Significant @ p $\leq .05$ level.

(b) What is the relationship between messages received from insurers and customer satisfaction?

Research Question two and the second hypothesis $\left(\mathrm{Ha}_{2}\right)$ were tested with Pearson Correlation and Multiple Regression Analysis. The correlation coefficients were $\mathrm{R}=.637$ and $\mathrm{R}^{2}=.406$ which suggested a moderately strong relationship between the relational messages and customer satisfaction.

The results also indicated that customer's personal value could be influenced by perceived commitment of insurers as expressed in messages received from insurers $(F=3.647 p<.035$, Table 9). The variable commitment also was found to have significant $t$ coefficient value with $p \leq .042$. Therefore, the regression equation could be expressed as follows:

Relational Message $=.725+.106$ (message meaning $)+.385$ (commitment) + .202(channels) + error. Moreover, the coefficient t scores, which test the significance of the variables was $p \leq .042$. Hence, $\mathrm{H}_{2}$ could not be rejected on commitment (Table 10).

Table 8: Model Summary

\begin{tabular}{|c|c|c|c|c|}
\hline & $\mathrm{R}$ & $\mathrm{R}$ Square & $\begin{array}{c}\text { Adjusted R } \\
\text { Square }\end{array}$ & $\begin{array}{l}\text { Std. Error of the } \\
\text { Estimate }\end{array}$ \\
\hline 1 & .637 & .406 & .295 & .502 \\
\hline
\end{tabular}

Table 9: ANOVA

\begin{tabular}{|c|l|c|c|c|c|}
\hline Model & \multicolumn{1}{|c|}{$\begin{array}{c}\text { Sum of } \\
\text { Squares }\end{array}$} & df & Mean Square & $\mathrm{F}$ & Sig. \\
\hline Regression & 2,761 & 3 & .920 & 3.647 & .035 \\
1 Residual & 4.039 & 116 & .252 & & \\
Total & 6.800 & 119 & & & \\
\hline
\end{tabular}


INDEPENDENT JOURNAL OF MANAGEMENT \& PRODUCTION (IJM\&P)

http://www.ijmp.jor.br

v. 10, n. 1, January - February 2019

ISSN: 2236-269X

DOI: 10.14807/ijmp.v10i1.829

Table 10: Regression Coefficients

\begin{tabular}{|c|c|c|c|c|c|c|}
\hline Model & $\begin{array}{l}\text { Unsta } \\
\text { Coeffi } \\
\text { B }\end{array}$ & $\begin{array}{l}\text { dardized } \\
\text { ent } \\
\text { Std.Error }\end{array}$ & $\begin{array}{c}\text { Standardized } \\
\text { Coefficient } \\
\text { Beta }\end{array}$ & $t$ & Sig. & Remarks \\
\hline Constant & .725 & & & .743 & .468 & NS \\
\hline $\begin{array}{l}\text { Meanings of } \\
\text { Message }\end{array}$ & -.106 & 160 & . 154 & .665 & .516 & NS \\
\hline $\begin{array}{c}\text { Relational } \\
\text { Commitment }\end{array}$ & .385 & 192 & .463 & 2.004 & .042 & S \\
\hline $\begin{array}{c}\text { Communication } \\
\text { Channels }\end{array}$ & .202 & 202 & 198 & .997 & .334 & NS \\
\hline
\end{tabular}

Legend: NS = Not Significant; $S$ = Significant @ $p \leq .05$ level.

(c) Are there were any differences in the levels of association of received messages with service quality by male and female insurance customers?

The third research question and the relevant hypothesis $\left(\mathrm{H}_{3}\right)$ were tested with one-way ANOVA for differences in the mean of male and female samples. The results indicated that customer perceptions of service quality were significantly different between male and female customers who participated in the survey $(F=$ $.020, p \leq .888$ for expected standards; $F=.002, p \leq .966$ for empathy; $F=3.72, p \leq$ .070 for perceived value; and $F=2.505, p \leq .131$ for reliability).

A further test with Levene Statistics of Homogeneity of Variances indicated that only one service quality variable, namely, customer value was differently perceived between the male and female participants. Hence, the hypothesis $\left(\mathrm{H}_{3}\right)$ was rejected for all four variables (expected standards, empathy, perceived value, and reliability).

Table 11: One-way ANOVA

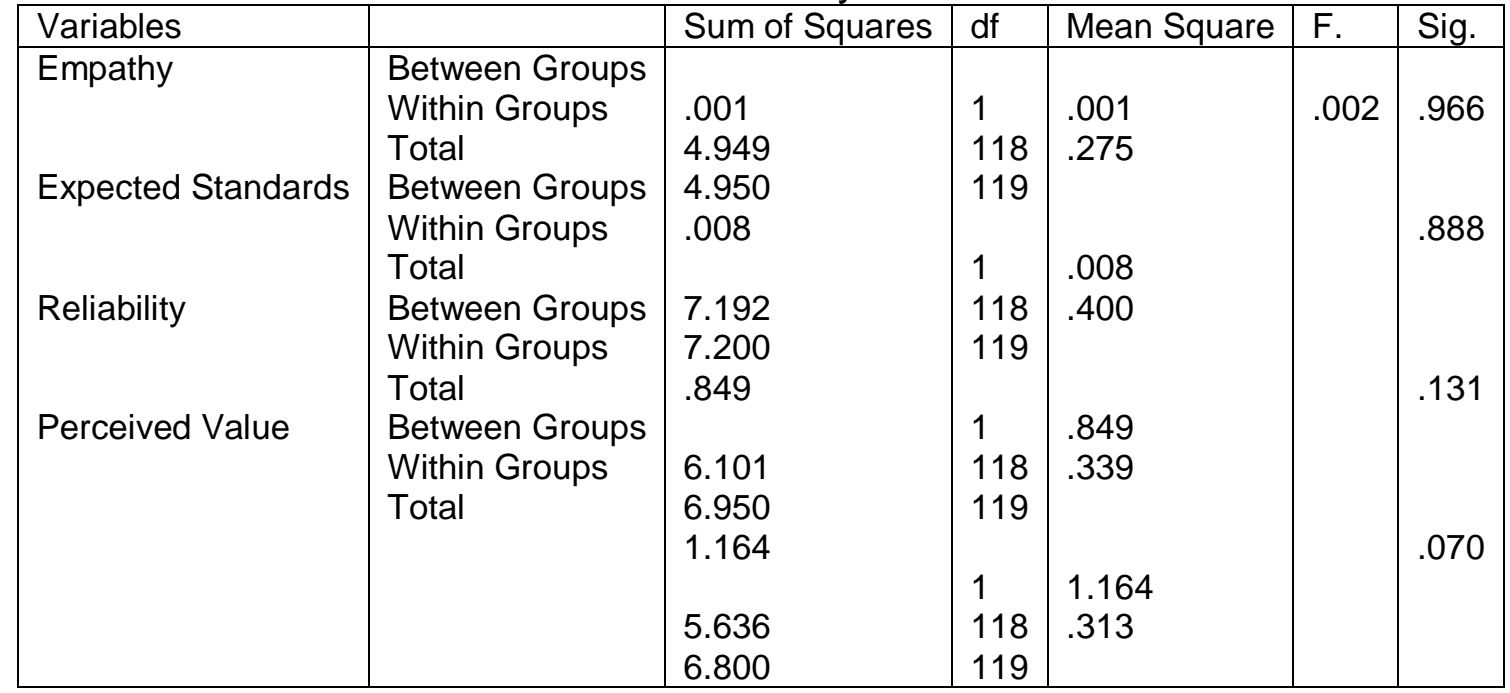


DOI: 10.14807/ijmp.v10i1.829

Table 12: Test of Homogeneity of Variances

\begin{tabular}{|l|l|l|l|l|l|}
\hline Variables & Levene Statistics & df1 & df2 & Sig. & Remarks \\
\hline Empathy & .007 & 1 & 118 & .932 & NS \\
Expected Standards & .180 & 1 & 118 & .676 & NS \\
Reliability & .209 & 1 & 118 & .653 & NS \\
Expected Value & 5.164 & 1 & 118 & .036 & S \\
\hline
\end{tabular}

Legend: NS = Not Significant; $S=$ Significant @ $p \leq .05$ level

(d) Are there differences in the perceptions of relational messages and customer satisfaction depending on gender?

Research question four and the relevant hypothesis were tested with one-way ANOVA to determine whether there were also significant differences in the perception of the respondents on how the insurers' relational messages could influence customer satisfaction based on gender. The results were $F=.029, p<.866$ for responsiveness; $F$ $=1.871, p<.188$ for credibility; and $F=3.267, p<.087$ for assurance (physical evidence).

A further test with Levene Statistics also confirmed significant differences between male and female respondents in the perception of credibility in relational messages as related to customer satisfaction. Hence, $\mathrm{H}_{4}$ was rejected on responsiveness, assurance (physical evidence), but not rejected for credibility since the significant levels for credibility was $p \leq .005$, which was less than $p \leq .05$ as shown in the Levene Test of Homogeneity (Table 13).

Table 13: One-way ANOVA

\begin{tabular}{|c|c|c|c|c|c|c|}
\hline Variables & & $\begin{array}{l}\text { Sum of } \\
\text { Squares }\end{array}$ & df & $\begin{array}{l}\text { Mean } \\
\text { Square }\end{array}$ & $F$ & Sig. \\
\hline \multirow[t]{4}{*}{ Responsiveness } & $\begin{array}{l}\text { Between } \\
\text { Groups }\end{array}$ & .013 & 1 & .013 & .029 & .866 \\
\hline & Within Groups & 7.737 & & & & \\
\hline & Total & 7.750 & 118 & 430 & & \\
\hline & Between & & 119 & & & \\
\hline \multirow[t]{4}{*}{ Credibility } & $\begin{array}{l}\text { Groups } \\
\text { Within Grouns }\end{array}$ & $\begin{array}{l}584 \\
5616\end{array}$ & 1 & & & \\
\hline & Total & 6.200 & 119 & .584 & & \\
\hline & $\begin{array}{l}\text { Between } \\
\text { Groups }\end{array}$ & 3.564 & & .312 & 1.871 & 188 \\
\hline & Within Groups & & & & & \\
\hline $\begin{array}{l}\text { Assurance (physical } \\
\text { Fvidence) }\end{array}$ & Total & 19.636 & 118 & 3.564 & & \\
\hline Evidence) & & 23.200 & 119 & 1.091 & 3.267 & .087 \\
\hline
\end{tabular}

Table 14: Test of Homogeneity of Variances

\begin{tabular}{|l|c|c|c|c|}
\hline \multicolumn{1}{|c|}{ Variables } & Levene Statistics & df1 & df2 & Sig. \\
\hline Responsiveness & .004 & 1 & 118 & .948 \\
Credibility & 10.275 & 1 & 118 & .005 \\
Assurance (Physical Evidence) & .291 & 1 & 118 & .596 \\
\hline
\end{tabular}




\section{DISCUSSION}

The goal of this research was to identify how insurance customers perceive messages they receive from insurers. The study also sought to analyze the inherent differences in the perception of relational messages between male and female customers with regards to service quality and customer satisfaction.

It was my belief that with the paradigm shift in marketing from transactional orientation to a more customer-centric communication pattern in many organizations, there was an inherent gap which needs to be addressed with regard to understanding of the communication needs of insurance customers.

That apprehension was verified through a review of extant literature which also confirmed the dearth of empirical studies that link communication patterns in the insurance sector to the personal values of customers.

Contemporary literature on relationship marketing and communications has also confirmed the yearning gap between the existing theories and actual practice of relationship communication in the insurance sector. This study has provided some insight into how the communication gaps could be addressed.

The study has also verified the relevance of relational messages as an effective tool for bridging the gaps in the perceptions of insurance customers about insurers' credibility and future promises delivery. The findings are in line with Finne and Gronroos (2009, p. 186) proposition that "meaning creation" forms the nexus of relationship communication. Where negative meanings are created, the perceptions of customers are also negatively affected with the consequences of customers' apprehension on matters pertaining to service quality and customer satisfaction. Undoubtedly as Festinger (1957) revealed, apprehension by customers could result in "cognitive dissonance" or perceived regrets on the existing relationship.

Another important contribution of the study is the corroboration of the significance of time and situation which was earlier posited by Gronroos (2000) as the key dimensions of "meaning creation in relationships, which are established, maintained, and enhanced over time" (p. 243).

The study confirms that messages transmitted to customers which ignore the convenience or otherwise of time and situation may be perceived negatively by customers. Meaning creation as the lexicon for interpretation of relational messages 
INDEPENDENT JOURNAL OF MANAGEMENT \& PRODUCTION (IJM\&P)

http://www.ijmp.jor.br

v. 10, n. 1, January - February 2019

ISSN: 2236-269X

DOI: 10.14807/ijmp.v10i1.829

has been an area that researchers and many organizations have ignored in the past (STEWART, 1998; RODRIGUES; FERNANDES, 2018).

The insurance industry had been found to be no exception in overlooking the internal and external values of customers in most communications and business relationships. This study has reaffirmed the need for a paradigm shift in line with modern practices which focus on effective relationship communication with customers.

\section{IMPLICATIONS AND CONCLUSION}

The old adage of marketing is that business begins and ends with the customer. Customer is the central force that drives a business relationship. Therefore, insurance companies need to treat the customer as the beginning, the central focus, and the end receiver of all marketing and business communication strategies.

The centrality of relationship communication as an influencing tool in insurance business relation should not be overlooked. Relationship communication differs from other forms of communication because of the relative meanings attached by the receiver of messages. Receivers may interpret or perceive messages based on specific mind-sets or past experience as well as the expected future situations. Such situations constitute a major part of the receiver's threshold of meanings associated with messages.

The need to carefully identify and analyze specific circumstances which could motivate the customer to interpret and ascribe positive meanings to messages received in a business relationship should be emphasized. Such analysis may reveal the costs and benefits of adaptation or customization of messages rather than overemphasizing generic messages which may not accommodate the variegated needs of customers. Communication should be seen as the lifeblood of effective relationship in a highly competitive and largely integrated contemporary marketing environment.

\section{LIMITATIONS AND NEED FOR FURTHER STUDIES}

This study was exploratory and subject to some limitations. One of the limitations was the size of the sample. The sample was not very large and the scope 
of coverage was limited to only three states that were covered by the insurance agencies.

The sample size and the composition of the respondents could affect the generalizability of the findings. There is therefore the need for a further study that would cover a larger size of sample, which would be more representative of the insured population in the selected geographical areas.

Another limitation of the research was the fact that all respondents were auto insurance policyholders. Future studies should try to expand the sample frame to include customers who hold other non-life and life policies. The major strength of the study lies in the high validity and reliability of the variables which were mainly derived from some of the major literature and past research studies in relationship marketing and communications. Further studies may need to identify other key variables of communication that could influence insurance consumers' perception of relationship and how they are connected with service quality and customer satisfaction.

\section{REFERENCES}

ABUROUB, A. S.; HERSH, A. M.; ALADWAN, K. (2011) Relationship between internal marketing and service quality with customer satisfaction. International Journal of Marketing Studies, v. 3, n. 2, p. 107-118.

AGGARWAL-GUPTA, M.; KUMAR, R. (2012) Look who's talking! Impact of communications relationship satisfaction on justice perceptions. The Journal for Decision Makers, Indian Institute of Management: VIKALPA, v. 35, n. 3, p. 55-64.

ALLERD, A. T. (2001) Employeesevaluations of service quality in banks and credit unions, The International Journal of Banking, v. 19, n. 4, p. 179-185.

ANDERSON, E. W.; FORNELL, C.; MAZVANCHERYL, S. K. (2004) Customer satisfaction and shareholder value. Journal of Marketing, n. 68, p. 172-185.

AXLEY, S. R. (1984) Managerial and organizational communication in terms of the conduit metaphor. Academy of Management Review, n. 9, p. 428-437.

BERLO, D. K. (1960) The process of communication: An introduction to theory and practice. New York: Holt, Rinehart \& Winston.

BERRY, L. L. (1983) Relationship marketing, in: BERRY, L. L.; SHOSTACK, G. L.; UPAH, G. (Eds.) Emerging perspective in service marketing. Chicago: American Marketing Association, v. 22, n. 2, p. 114-135.

BERRY, L. L. (1995) Relationship marketing of services---Growing interest, emerging perspectives. Journal of the Academy of Marketing Science, n. 23, p. 236-245. 
BOLTON, R. N. (1998) A dynamic model of the duration of the customer's relationship with a continuous service provider: The role of satisfaction, Marketing Science, v. 17, n. 1, p. 45-65.

BOLTON, R. N.; BHATTACHARYA, C. B. (2000) Relationship marketing in mass markets, in Handbook of Relationship Marketing, SETH, J. N.; PARVATIYAR A. (Eds.) Sage Publications: Thousand Oaks, CA, pp. 37-54.

BOLTON, R. N.; LEMON, K. N.; VERHOEF, P. C. (2004) The theoretical underpinning of customer asset management: A framework and propositions for future research, Journal of the Academy of Marketing Science, n. 32, p. 271-292.

CROSBY, L. A.; EVANS, K. R.; COWLES, D. (1990) Relationship quality in service selling: An interpersonal influence perspective. Journal of Marketing, n. 52, p. 2134.

CHEN, Z. X.; SHI, Y.; DONG, D. H. (2008) An empirical study of relationship quality in a service setting: A Chinese case. Marketing Intelligence and Planning, v. 26, n. 1, p. 11-25.

DUNCAN, T. (2005) Principles of advertising and integrated marketing communication (IMC), $2^{\text {nd }}$ ed. New York: McGraw-Hill Irwin.

DUNCAN, T.; MORIARTY, S. (1997) Driving brand value, New York: McGraw-Hill. FESTINGER, L. (1957) Explanations in cognitive dissonance, New York: Wiley.

FINNE, A.; GRONROOS, C. (2009) Rethinking marketing communication: From integrated marketing communication to relationshipcommunication. Journal of Marketing Communications, v. 15, n. 2-3, p. 179-195.

FORNELL, C. (1992) A national customer satisfaction barometer: The Swedish experience. Journal of Marketing, n. 56, p. 6-22.

FORNELL, C.; JOHNSON, M. D.; ANDERSON, E. W.; CHA, J.; BRYANT, B. E. (1996) The American customer satisfaction index: Nature, purpose, and findings. Journal of Marketing, n. 60, p. 7-18.

GIDHAGEN, M. (1998) Insurance marketing: Services and relationships. Working Paper, 4, Uppsala University, Department of Business Studies, Uppsala: Sweden.

GRONROOS, C. (2000) Service management and marketing: A customer relationship approach. London: John Wiley \& Co.

HUTTON, J. G.; MULHERN, F. J. (2003) Marketing communications: Integrated theory, strategy \& tactics. West Paterson, NJ: Pentagram.

KODISH, S.; PETTEGREW, L. S. (2008) Enlightened communication is the key to building relationships. Journal of Relationship Marketing, v. 7, n. 2, p.151-176.

KOTLER, P. (2003) Marketing management: Analysis, planning, implementation and control. New York: Prentice Hall.

KOTLER, P.; KELLER, K. L. (2012) Marketing management. Global edition (14th). London:Pearson

KRAUSS, R. M.; MORSELLA, E. (2000) Communication and conflict, in M. Deutsch and P. T. Coleman (Eds.) The handbook of conflict resolution theory and practice. San Francisco: Jossey-Bass 
MITHAS, S.; KRISHNAN, M. S.; FORNELL, C. (2005) Why do customer relationship management applications affect customer satisfaction? Journal of Marketing, v. 69, p. 201-209.

MARSEY, P. A.; MARTIN, C.; CLARK, M.; PECK, H. (1995) Relationship marketing for competitive advantage: Winning and keeping customers, Oxford: Butterworth-Heinemann Ltd.

MASSEY, G. R.; DAWES, P. L. (2007) The antecedents and consequence of functional and dysfunctional conflict between marketing managers and sales managers, Industrial Marketing Management, v. 36, n. 8, p. 1118-1129

PARASURAMAN, A.; ZEITHAML, V. A.; BERRY, L. L. (1998) Servqual: A multipleitem scale for measuring consumer perception of service quality, Journal of retailing, v. 64, n. 1, p. 12.

PERCY, L.; ELLIOTT, R. (2005) Strategic advertising manage2000ment, ( $2^{\text {nd }}$ ed.), Oxford: Oxford University Press

PICKTON, D.; BRODERICK, A. (2005) Integrated marketing communications, $\left(2^{\text {nd }}\right.$ ed.), Harlow: FL Prentice Hall

RODRIGUES, P. C. C.; FERNANDES, E. M. S. (2018) Analysis of the data on the quality expectation in school services, from the student's perception. $4^{\circ}$ Congresso Internacional de Logística e Operações do IFSP, Suzano, Brazil

SHARMA, N.; PATTERSON, P. G. (2000) Switching costs, alternative attractiveness and experience as moderators of relationship commitment in professional consumer services, International Journal of Service Industry Management, v. 11, n. 5, p. 470-490.

SHETH, J. N.; PARVATIYAR, A. (1995) The evolution of relationship marketing, International Business Review, v. 4, n. 4, p. 397-418.

SORCE, P. (2002) Relationship marketing strategy, Rochester Institute of Technology, NY: Alfred P. Sloan Foundation Center

STEWART, D. W. (1998) The market-back approach to the design of integrated communications programs: A change in paradigm and a focus on determinants of success. In GRONSTEDT, A.; SIRACUSE, L. (Eds.), The ABC's of IMC: Building blocks for integrated marketing communications (p. 23-29), New York: Advertising Research Foundation.

TANNEN, D. (1990) You just don't understsnd women and men in conversation. New York: Ballentine Books.

THRASSOU, A.; VRONTIS, D. (2009) A new customer relationship Model: The marketing communication Application. Journal of Promotion Management, n. 15, p. 499-521.

VERHOEF, P. C. (2003) Understanding the effect of customer relationship, Journal of Marketing, v. 67, p. 30-45.

WAGNER, J. A.; HOLLENBECK, J. R. (2010) Organizational behavior: Securing competitive advantage. New York: Taylor \& Francis Group.

YANG, L.; CHEN S.; WANG, Y. (2010) The essence of customer relationship management: The case of Taiwan's insurance industry. Catholic University, Fu Chen: Taiwan 
WOOD, J. (2009) Gendered lines: Communication, gender and culture (8th Ed.) Belmonth CA: Wadsworth Publisher.

ZEITHMAL, V. A.; BITNER, M. J. (2003) Services marketing integrating customer focus across the firm, ( $3^{\text {rd }}$ ed.), New York: McGraw Hill.

ZEITHMAL, V. A.; PARASURAMAN, A.; BERRY, L. (1990) Delivering quality service: Balancing Customer perceptions and expectations. New York: The Free Press.

\section{APPENDIX 1A}

\section{Survey Questionnaire}

Dear Respondent,

I am conducting a survey to understand how insurance customers perceive the existing business relationship with their insurers. The main aim is to see how insurance business relationships could be sustained through improved communication and service quality. We believe you can participate in the exercise by taking a few minutes to complete the following questionnaire. Please note that information given will be used strictly for research purposes. Due confidentiality will be maintained, and you are not obligated to buy products or services from any company.

Part A

Do you hold any insurance policy? Yes No

1. If you hold or intend to hold a policy, please rank the following factors from 1 to 5 ( $1=$ very important, $2=$ important, $3=$ neutral, $4=$ unimportant, and $5=$ very unimportant) with regards to your choice of an insurer or insurance company.

\begin{tabular}{l|l} 
List of Factors: & Rank
\end{tabular}

Accessibility of the company-----|-----------

Evidence of Performance

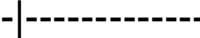

Product Information Brochure----|-----------

Persuasive Advertisement-

Initial Cordial Response$-1$

Part B

Please rate the following statements according to how you see your existing business relationship with your insurers.

\begin{tabular}{|l|l|l|l|l|l|l|}
\hline $\begin{array}{l}\text { Serial } \\
\text { Numbers }\end{array}$ & Statements & 1 & 2 & 3 & 4 & 5 \\
\hline
\end{tabular}


DOI: 10.14807/ijmp.v10i1.829

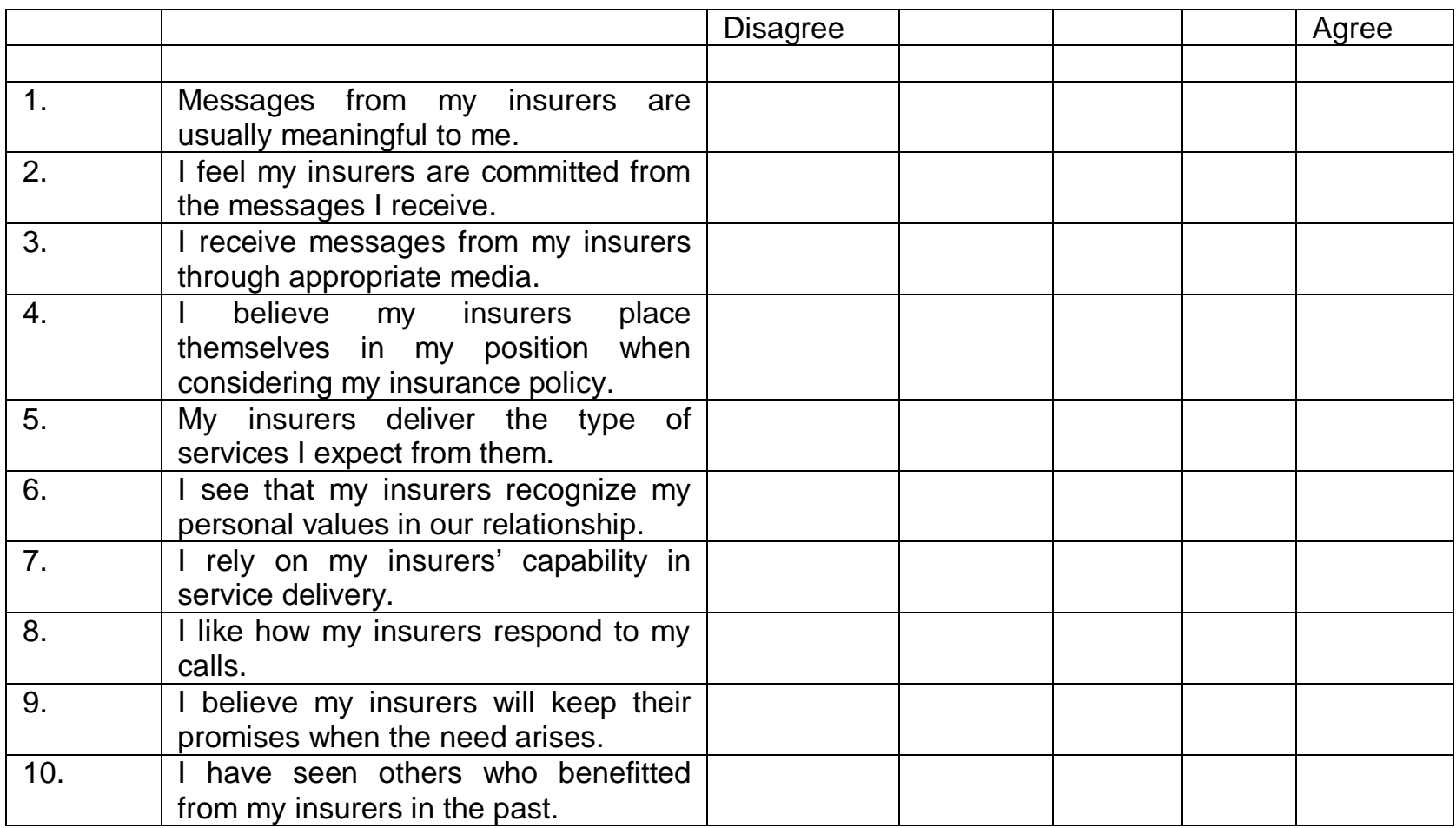

11. Please briefly explain the changes you would like to see in your insurance business relationship.

12. How would you rate the usefulness of information from your insurers pertaining to your insurance contract? (1) Very Useless

(4) Useful

(2) useless

Neutral-

13. Please indicate your level of satisfaction with your present insurer's relationship with you as a customer. (1) Indifferent------- (4) Satisfied-

(1) Very Dissatisfied

(2) Dissatisfied

14. All things considered, what are your main concerns with your insurers? (Please be explicit)

\section{Demographic Data}

Gender: (1) Male (2) Female

Age:

Educational Level: (1) High School Diploma Graduate (3) Post Graduate

(2) College/University

Marital Status: (1) Single (2) Married (3)

Separated (4) Divorced (5) Widowed

Occupation: (1) Unemployed (4) Professional (2) Student (3) Private Sector Employee (5) Public Sector Employee

State of Residence (USA):

Thank you for your assistance.

Dr. Andem I. Effiong, 
ISSN: 2236-269X

DOI: 10.14807/ijmp.v10i1.829

DBA (WilmU, USA), M.Phil. (Unilag), MBA (St. John's, New York), BBA (St. John's, NY) 